\title{
JOURNAL.RU
}

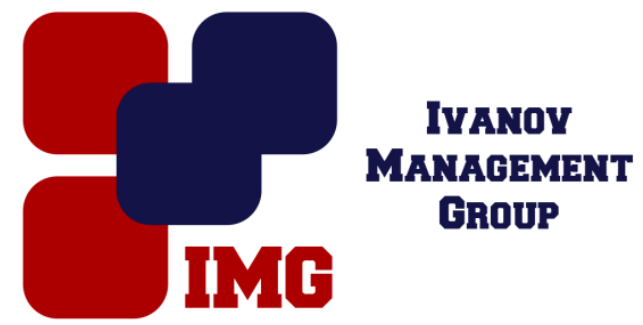

Бехтер А.Ю., Бутров Н.А., Хайров М.А.

Пензенский государственный университет

Пенза, Россия

doi: $10.18411 / 1 \mathrm{j}-30-06-2017-47$

idsp 000001:1j-30-06-2017-47

\section{Необходимость владения иностранным языком для будущих специалистов технического профиля}

\section{Аннотация}

Изучение иностранного языка в неязыковом вузе в значительной степени способствует развитию профессионального и личностного саморазвития будущих специалистов. В процессе обучения иностранным языкам студенты неязыкового вуза отмечают рост интереса к своей специальности, что способствует формированию внутренней положительной мотивации на профессиональное становление, а значит и стимулом развития личности в целом.

Ключевые слова: неязыковой вуз, иностранный язык, технические специальности.

В современном обществе нельзя не заметить возрастание значимости знания иностранного языка, в особенности английского, так как он насчитывает порядка 840 миллионов носителей (для 340 из которых он является родным). Китайский язык, например, насчитывает около 1,2 миллиарда носителей, но он не слишком распространен за пределами своей страны. Исходя из информации о распространенности можно сделать вывод, что знание английского языка открывает новые возможности, такие как доступ к новой информации, перспективы устройства на работу за границей, путешествия так же станут более комфортными. Нельзя забывать и о технической важности данного языка, часть 
программных сред и оболочек для них сделаны на английском языке без возможности перевода на русский.

В современных условиях вопрос конкурентоспособности российского образования, его эффективности и ключевой роли в развитии страны является очень важным. Требования рынка труда к квалификации выпускника также заметно возросли. Подготовка конкурентоспособного работника в любой области труда не должна сводиться только к обеспечению высокого уровня его профессиональной компетенции. Специалист должен получить также и социальную подготовку, которая осуществляется посредством обществоведческих и гуманитарных дисциплин. В настоящее время работодатель, в условиях обостряющейся конкуренции, предъявляет свои требования, которые зачастую выходят за рамки образовательных стандартов. Одним из таких требований является владение одним или несколькими иностранными языками. Получение качественного языкового образования расширяет возможности трудоустройства выпускников технических вузов, участия в международных программах и продолжения обучения за рубежом, а также повышает их конкурентоспособность на рынке труда.

Вся жизнь людей, как она видится на протяжении тысячелетий, - это накопление опыта и передача его следующим поколениям. Каждое новое поколение овладевает накопленным опытом, учится пользоваться им. И само вносит в общую копилку знаний и умений новые сведения, полученные в течение всей жизни. Поэтому обучение всегда было одной из основных забот людей. Появление компьютеров с их широкими возможностями обработки и поиска информации, отображения ее в удобной для человека форме натолкнули исследователей на идею компьютерного обучения. Появление таких систем открыло эру автоматизированных обучающих систем (АОС). АОС содержат базу знаний об изучаемом объекте, специальные средства для выдачи информации ученику и контроль за уровнем усвоения знаний. В развитых АОС имеются специальные средства для тестирования обучаемого и подбора для него наилучшей стратегии обучения. Основу любого автоматизированного рабочего места составляет персональная электронно-вычислительная машина в сочетании с устройством отображения информации. Кроме того, в зависимости от вида деятельности специалиста на том или ином АРМ в состав его оборудования могут входить средства телефонной и радиосвязи (АРМ диспетчера), комплекс измерительных приборов, анализаторов и т.п. (АРМ исследователя), приборы контроля и автоматической регистрации параметров технологических процессов 
(АРМ технолога), комплекс автоматизированных устройств и инструментов (АРМ монтажника микроэлектронных приборов) и т.д. Например, на рабочем месте конструктора установлена ЭВМ с набором устройств хранения, обработки, регистрации и отображения графической и символьной информации, облегчающих расчет и оптимизацию формы проектируемой детали, поиск унифицированных и нормализованных примеров из соответствующих справочных банков данных. На автоматизированном рабочем месте инженер быстрее сможет подготовить рабочую документацию. Работа конструктора на АРМ построена в режиме диалога с машиной, что позволяет быстро делать исправления в документах и одновременно выдавать исходную информацию для технолога.

Рабочее место технолога тоже автоматизировано. С помощью ЭВМ он разрабатывает практически весь технологический процесс. ЭВМ составляет программу обработки, в которой предусмотрены форма и размеры заготовки. Основываясь на конструкторской документации, ЭВМ выбирает обрабатывающий элемент и т.п. При правильном использовании автоматических рабочих мест производительность труда технолога повышается в десять и более раз. Наряду с распечатанным описанием технологического процесса технолог получает управляющую программу для обрабатывающей машины, например станка с числовым программным управлением.

Для нас, как для будущих инженеров необходимы знания о достижениях науки и техники, отечественного и зарубежного опыта в сфере организации производства. Решение подобных задач невозможно без анализа зарубежных публикаций и обмена информацией на иностранном языке, общения на форумах с зарубежными партнерами; составления и перевода технической документации с описанием функционирования и технического обслуживания различных устройств. Например, для специалиста в области информатики и программирования знание иностранного языка очень важно. Различные программы создаются на иностранном языке, так как фирмы часто заключают договоры с иностранными инвесторами. И чтобы работать с программой, надо знать иностранный язык. Изучение иностранного языка - это уже первая ступень для более углубленного изучения языка программирования и для большего профессионализма в области информатики. При переводах знание языка помогает избегать малейших ошибок и неточностей, а это может помешать дальнейшей работе или привести к сбою в системе. Так же сегодня предлагается много технической информационной литературы, в которой без 
знания языка не так просто разобраться или вообще практически невозможно. Знание иностранного языка увеличивает возможность продвижения по карьерной лестнице. Некоторые фирмы посылают молодых специалистов в другие страны для повышения квалификации. Увеличивает круг общения со специалистами в той или иной области не только с англичанами, но и с другими странами, ибо английский язык является международным. К тому же есть возможности работать или дальнейшего обучения в других странах, а не только командировочные поездки по специальности.

Изучение иностранного языка также призвано обеспечить развитие комплекса общекультурных и общенаучных компетенций, включая: воспитание толерантности и уважения к духовным ценностям разных стран и народов; развитие информационной культуры; расширение кругозора и повышение общей культуры студентов и т.д.

И в заключении необходимо отметить, что на сегодняшний день, говоря о высококвалифицированном специалисте, мы отмечаем не только его (специалиста) узконаправленные профессиональные качества, но это ещё и специалист со знанием иностранного языка. 